DOI: 10.28934/jwee19.12.pp71-79

PROFESSIONAL PAPER

\title{
Assessing Institutional Founding Sources and Challenges Facing Women Entrepreneurs in Nigeria
}

\author{
Ann Terngu Makar Vandefan ${ }^{1}$ \\ University Business Academy, FIMEK, Novi Sad, Serbia
}

\begin{abstract}
A B S T R A C T
This paper examines the institutional and other funding sources available for women entrepreneurs in Nigeria and the challenges faced by them in accessing these funds. The paper reveals various policies from previous governments that were aimed at exposing women entrepreneurs in Nigeria to funds through establishment of micro credit institutions in realization of the pivotal role women have in economic development most especially in small scale enterprises within ruler communities.
\end{abstract}

KEY WORDS: Nigerian women entrepreneur, institutional funding sources

\section{Introduction}

Female entrepreneurship long went virtually ignored in the academic literature and real life of many countries (Radovic-Markovic, 2013).There is a general belief that entrepreneurs are people who take advantage of an existing economic opportunity or investment at a small scale and are passionate about their investment and what they do according to Hefsky (2011), this encourages them to take the risk to realize their dreams.

\footnotetext{
${ }^{1}$ Address: Cvečarska 2, Novi Sad, Serbia, e-mail: magtvan@gmail.com
} 
In developing economy such as Nigeria, women are known to play vital roles in keeping the family going through their entrepreneurs are skills where they seems to augment men who are low income earners or those who lost their jobs. This is done through creative ideas and capital input in the economy by establishing microenterprise.

Nigerian women entrepreneurs are a perfect match for this description as they are continually engaging in new economic ventures like tailoring, sewing, food venturing and a host of other areas like water packaging in sachets and garri production using cassava tubers.

It is based on these narratives that many researchers are of the opinion that an entrepreneur is not just someone who take risk and creates new ventures but is actually someone that ensures the growth of his business by being innovative and applies strategic principles that can guarantee the survival and growth of her investment. According to Miskin and Rose (2015), an entrepreneur is indeed one who is innovative in pursuing the economic investment to make profit and realize some growth and is willing to be risk averse.

This is the reason why women contributes significantly to the economic growth of any nation through the establishment of all kinds of economic ventures at the small and medium scales to support the family, society and the country where they resides. Iyiola and Azhu (2014) captured this development as a process where women create ideas that create job opportunities for suppliers and other business ventures.

In Nigeria, women engaged in micro business to support their husbands' low earnings where Garba (2011) concludes that they do this for the family survival besides their motherly roles of reproduction. This has been recognized by many donor agencies as a pivotal agent of poverty reduction hence most international organizations now support women to finance their investment to augment their income and reduce dependency on men alone as observed by Carrington (1994) This viewpoint is based on the challenging economic difficulties that women are faced with in poor and developing African countries like Nigeria. It is based on this realization that Iyiola and Azhu (2014) agreed that women in Nigeria are major players in economic development as they generate employment opportunities in rural areas thereby reducing poverty. This is why Miskin and Rose (2015) portrayed entrepreneurs as the inventors and an 'innovative' economic organization that targets gains and growth under condition of risk and uncertainties. 
There are numerous sources of funding available in Nigeria for women who are engaged in small scales enterprise over the years since the inception of democracy in 1999. However, there are bureaucracies associated with accessing these funding and also the questions of where to get the needed collaterals. This is worrisome because women hardly owe properties moveable and immovable in their names so it became an obstacle to meet the security needed by such institutions to release funds to women in Nigeria to invest.

Majority of operators of informal businesses like street fruits shops to apple and food vendor shops are operated by women in Nigeria. This is also confirmed by research that this informal sector accounts for almost half of economic activities in the country (Soetan, 1997; Thomson, 2002; Aina, 2003; Garba, 2011).

There are other factors that limit the full potentials of women in investing in small business in Nigeria which ranges from political, socio economic, cultural and family factors. Despite all these, women are seen as opium of change in the Nigerian economic development as they are also considered less corrupt and more committed in avoiding failure in their chosen entrepreneur skills where most of them focused essentially on preventing hunger in the family by eating the profit and rolling over the capital so as to keep the family happy and prevent them becoming a problem to the immediate communities where they resides. This accounts for the reason why most women do their business along the streets, bus stops and motor parks in Nigeria.

\section{Literature Review /Conceptual Frame Work}

Nigeria has an estimated population of about 190 million people within which about 162 million are poor and out of this figure, women account for the highest number of the poor (Adepelumi, 2011), this represents one of the world highest and worst poverty level. Although there have been many poverty alleviating programs for women entrepreneurs in Nigeria since the oil boom era of the 1970s, these programs were to augment the sources of funding for women entrepreneurs in Nigeria.

These programs were named according to the successive military regimes as Operation Feed the Nation (OFN), Green Revolution (GR) among various agricultural guarantee schemes and agricultural credit facilities that were specifically targeted towards women entrepreneurs. Peoples bank was 
also introduced to target rural women and community banks too to give small credits to women in rural areas, these projects were between 1970 and 1999.

According to Adepelumi, (2011), these programs are classified as pre and post Structural Adjustment Programs (SAP).Various governments in Nigeria introduced rural electrification programs and free adult education to encourage Nigerian women entrepreneurs to embark on micro businesses in communities to reduce poverty and encourage increased agriculture programs. The military regime has to complement these programs by establishing the National Commission for Women (NCW) where women project related programs could be coordinated so that women will have more access to entrepreneur skills and financing.

The democratic dispensation of 1999 created a federal ministry for women affairs to compliment the role of NWC where all issues inhibiting the effective involvement of women in economic development will be addressed. The Buhari administration of 2015 introduced other social intervention schemes like the market money where women are given 10000 naira as interest free loan and the only collateral is that a woman must owe a shop where she sells. The regime introduced graduate employment scheme known as N-power that hires mostly young women graduates to offer complementary support services to communities.

Although government at all times has tried to make available some incentives to support Nigerian women entrepreneur to succeed, but a number of factors inhibits their success and access to these funding lines due to several challenges such as low capital start off business, high degree of failure rates by women in similar ventures, low productivity and difficulty accessing available credit lines. These factors have limited the successes of Nigerian woman enterprise even though some have overcome these challenges and are making tremendous stride in their businesses. (Soetan, 1997; Thomson, 2002; Aina, 2003; Farrington, 2006; Barrett, 2006; Mordi, Simpson, Singh and Okafor, 2010; Arenius and Minniti, 2003).

These challenges are similar in all the states selected in the six geopolitical regions in Nigeria. These challenges can be overcome if the literate levels of Nigerian women who are involved in entrepreneurship are enhanced (Aina, 2003).Nigerian women enterprises are also not conscious of environmental and economic risk in their investment program. Garba (2011) correctly observed that, men have more propensities to risk taking than women in Nigeria and this accounted for the reason why men are more suc- 
cessful in entrepreneur business than women in Nigeria and since women are also poorer than men, it becomes difficult for them to approach banks for facility to invest in their business. (Iheduru, 2002; Thomson, 2002) since banks structure their loanable funds strictly for short term business and rigid collaterals with high interest rate and sometimes unexplained and concealed administrative charges.

Family constraints and religion are also factors that prevent effective involvement in business enterprise in Nigeria since men seem to prevent them from being victims of sexual intimidation and cruelty associated with business environments. This in most cases encourages women to depend largerly on finances of the father, husband or relation and creates dependency syndrome both on their needs and on the part of decision making. (Ghosh, Gupta and Dhar in Konungo, 1998; Mordi, Simpson, Singh and Okafor, 2010; Arenius and Minniti, 2003),

The high degree of failed businesses has discouraged others from venturing in similar enterprise in Nigeria. This has been largely due to women's inability to develop an alternative plan B for their business as opined by Mullins 2011. Social classification between men and w0omen is another area of constraint as men are always seen more involved during meetings and always seems to prevail over women in meetings and negotiations, presentation and competitions; Arenius and Minniti, 2003) This suggests that Nigerian women entrepreneurs naturally disadvantaged by this moral issues which adversely contributes and result to inferiority complex increasing her feelings of dependency which obviously affects her entrepreneurial growth rate and success (Lorber and Farrell, 1991; Mordi, Simpson, Singh and Okafor, 2010; Arenius and Minniti, 2003). These sometimes result in the question about the self confidence level of women towards their business as posited by Kirkwood, 2009 that men are more confidence in exploiting baseness opportunities than their female folks and more so men are also exposed to investment information than women and this inhibits the entrepreneurial prospects of women as lack of information is key to identifying available opportunities.(Mordi, Simpson, Singh and Okafor 2010) Both of them also agreed that. Family structure too is a constraint on the Nigerian woman enterprise as the married women are most a tome restrained from business venture to look after children and other domestic needs of the family.

Finally Emmanuel (2013) concludes that apart from the identifiable challenges stated here, Nigerian woman entrepreneur are constrained by 
inadequate government support, lacked access to land, religious and cultural restrictions, weak networking among women and gender discriminations

\section{Financial Support for Women as Entrepreneurs}

The major sources of founding in all the geo political regions in Nigeria is local thrift and loans cooperative societies and the contributions from churches and other age grade associations.

It is also noticed that most women have large children so it has been difficult making profit from the trade they engage in due to financial needs of the children for hospitals and other educational related expenses, these has been a problem for them meeting up the payment schedules stipulated in the loan agreements.

The restriction of some women by religion and family cultures makes it difficult for loanable funds to be granted some of them as guarantors have to come from the family members.

Violence and relocation of married couples is another area that restrict women having access to loanable funds as it is required for them to stay for a minimum period in a location before qualifying for the loans.

In summary, Emmanuel (2013) sums the challenges facing women entrepreneurs in Nigeria as family issues, lack of supports from governments and donor agencies, personal characteristics peculiar with women physiological nature, lack of access to capital, markets and adequate information. Other challenges identified to be peculiar with Nigerian women are gender discrimination, lack of adequate contacts and weak networking power, lack of access to critical assets such as land and equipment, cultural and religious barriers (Soetan, 1997; Aina, 2003; Olutunla, 2001; Emmanuel, 2013).

\section{Discussion}

Nigerian government should encourage women by providing more loanable opportunities to them that will not be difficult to access by removing all bureaucracies attached to the application and processing of such loans.

Loans to women entrepreneurs should be made as easy as similar credit institutions in Indonesia, china and Bangladesh since they are adjudged to have the world's most successful and efficient banks in the world in dealing with micro credit (Aina, 2003; Todaro and Smith, 2009). 
There should be frequent information to women about available investment potentials to improve the level of women participation in micro and medium businesses.

Women should not be restricted from forming associations or net working groups so that they can be able to access and evaluate existing business potentials available and sources of grants and funding.

Women should form cooperative societies supported by international donor agencies and relevant government institutions, these can make them know the available markets and type of investment they can explore that will be more productive and profitable to limit loss and high risk.

\section{Conclusion}

Based on the geo political analysis in this study, women entrepreneurship in Nigeria has different variation as those in the North are more protected by family and religious beliefs than the women from the Southern East, South West and South parts of Nigeria. There are variations in the levels of women empowerment in the country as women in the southern part of the country are more free from family restrictions than the ones in the north and national policies seems to favor them in places like Lagos and Calabar more than their counterparts in Benue and Taraba where religion and cultural values seems to make women less business active.

Women from the southern part of Nigeria and the North Central states are more business minded than the women from the North West and North East where religion restrict rural women from trading and other open market trading activities

\section{References}

[1] Adepelumi, P. A. 2011. Women Entrepreneurship as a tool for Economic Development in Nigeria, African Centre for Advocacy and Human Development (ACAHD)

[2] Aina, O. I. 2003. Small Enterprises Owned by Women in Nigeria, Policy and Practices in Africa, IDRC Publications, Vol. 14, No. 29, 1-90.

[3] Arenius, P., and Minniti, M. 2003. Women in Entrepreneurship, The Entrepreneurial Advantage of Nations: First Annual Global Entrepreneurship Symposium, United Nations Headquarters, 29 April 2003.

[4] Barrett, M. 2006.Women's Entrepreneurship in Australia: present and their future in C. Brush, N. 
[5] Emmanuel, C.L. 2013. Entrepreneurship, A Conceptual Approach, Second Edition, Pumark Nigeria Limited: 3 53-358.

[6] Farrington P, R. 2006. Women Entrepreneurs: How important are their perceptions? Academy of Entrepreneurship Journal Vol. 12, No. 1, pp. 1-15.

[7] Garba, S. A. 2011. Stumbling Block for Women Entrepreneurship in Nigeria: How Risk Attitude and Lack of Capital Mitigates their Need for Business Expansion, European Journal of Economics, Finance and Administrative Sciences, Vol. 36, Pp 38-49. Global Entrepreneurship Monitor (2012). GEM 2011 Global Report. Published online, http://www.gemconsortium.org.

[8] Gosh, Gupta and Dhar in Konungo. (1998). Entrepreneurship and Religion

[9] Hefsky, L. 2011. Entrepreneurs are made not born. McGraw Hill Professional, New York City, NY

[10] Iyiola, O. O. \& Azuh, D. 2014. Women Entrepreneurs as Small-medium Enterprise (SME) Operators and their roles in Socio-economic Development in Ota, Nigeria. International Journal of Economics, Business and Finance (2,1), 1-10.

[11] Iheduru, N. G. 2002. Women Entrepreneurship and Development: The Gendering of Microfinance in Nigeria. A paper Presented at the 8th International Interdisciplinary Congress on at Makeree University, KampalaUganda Women, 21-26 July.

[12] Laurie J. Mullins. 2011. Management and organizational behavior.

[13] Lorber, J. \& Farrell, S. A. 1991. The Social Construction of Gender. Sage Publication, Inc. California USA.

[14] Minniti, M. \& Arenius, P. 2003. Women in Entrepreneurship, The Entrepreneurial Advantage of Nations:

[15] Miskin and Rose. 2015. Enabling Agric-entrepreneurship and Innovation: Empirical Evidence and Solutions for Conflicts Regions and Transitoning Economics.

[16] Mordi, C., Simpson, R., Singh, S. \& Okafor, C, 2010. The Role of Cultural Values in Understanding the Challenges faced by Female Entrepreneurs in Nigeria, Gender in Management: An International Journal, Vol. 25, No. 1, pp. 5-21 2015 43(2 ) 21

[17] Ogundele, O. J., \& Opeifa, A. Z. 2003. Factors that Influence the Emergence, Behaviour and Performance of Entrepreneurs in Nigeria, The Abuja Management Review, (1, 2) June.

[18] Ogunleye, G. A. 2004. Small and Medium Scale Enterprises as Foundation for Rapid Economic Development in Nigeria, In Small and Medium Enterprises Development and SMIEIS, Effective Implementation Strategies (Ed.), By Ojo, A. T. Lagos, Maryland Finance Company and Consultancy Service Ltd. 
Vandefan, A. T., Facing Women Entrepreneurs in Nigeria, JWEE (2019, No. 1-2, 71-79)79

[19] Olutunla A. 2001. "Emerging Issues on Micro and Rural Financing in Nigeria” in Bullion, a Publication of the Central Bank of Nigeria, Volume 25 No. 1 January/March, pp64-71

[20] Radovic/Markovic, M. 2013. Female Entrepreneurship, Journal of Women's Entrepreneurship and Education, 2013, No. 1-2, 1-9.

[21] Singh, S., Mordi, C., Okafor, C., \& Simpson, R. 2010. Challenges in Female Entrepreneurial Development - A Case Analysis of Nigerian Entrepreneurs, Journal of Enterprising Culture: An International Journal, (18, 4), 435 - 460. Singleton,

[22] Soetan, F. 1997. Entrepreneurship and Nigerian Women - Is there any meeting Point? Small Enterprise Development, Vol.8, March. SPSS, Inc. (2003). SPSS 12.0 for Windows. [Statistical Analysis Computer Software] Chicago.

[23] Todaro and Smith. 2009. Economic development, $10^{\text {th }}$ edition

[24] Thomson 2002. The future of globalization: first published; 17 december 2002, https://doi.org/1111/1467-8594.00145. Published by Blackwell Publishing.inc.350 main street. Malden MA 02148, USA and 108 Cowley Road, Oxford OX4 IJF.UK

Article history: $\quad$ Received: 15 April, 2019

Accepted: 16 June, 2019 